\title{
Evaluation of antioxidant, a-glucosidase inhibition and acetylcholinesterase inhibition activities of Allium hookeri root grown in Korea and Myanmar
}

\author{
Joo Young Park, Kyung Young Yoon* \\ Department of Food and Nutrition, Yeungnam University, Gyeongsan 38541, Korea
}

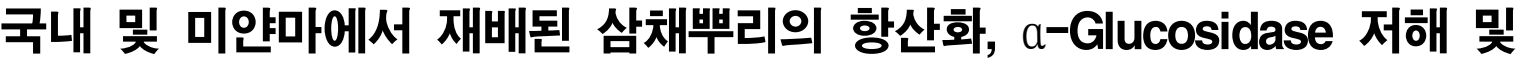 Acetylcholinesterase 저해 활성}

\author{
박주영 · 윤경영* \\ 영남대학교 식품영양학과
}

\begin{abstract}
This study was conducted to compare the functionality (antioxidant, anti-diabetic, and anti-dementia activities) of the methanol extract of Allium hookeri root grown in Korea (KR) and Myanmar (MR). The total polyphenol and flavonoid contents of KR and MR were 5.27 and $4.80 \mathrm{mg} \mathrm{GAE} / \mathrm{g}$, and 0.35 and $0.24 \mathrm{mg} \mathrm{QE} / \mathrm{g}$, respectively. KR contained significantly higher levels of total polyphenols and total flavonoids than those of $M R(p<0.05)$. The $I_{50}$ values of $K R$ and $M R$ were 6.53 and $5.31 \mathrm{mg} / \mathrm{mL}$, respectively, for DPPH radical scavenging activity. However, KR had a significantly higher ABTS radical scavenging activity, $\mathrm{Fe}^{2+}$ chelating ability, and reducing power compared with those of MR $(\mathbf{p}<\mathbf{0 . 0 5})$. In the evaluation of anti-diabetic activity, KR showed significantly higher a-glucosidase inhibition activity than acarbose and MR at whole concentrations $(\mathbf{p}<\mathbf{0 . 0 5})$. KR and MR had acetylcholinesterase inhibition activities that of $51.44 \%$ and $44.33 \%$, respectively, at a $50 \mathrm{mg} / \mathrm{mL}$ concentration. These results suggested that roots of $A$. hookeri, especially KR, could be useful in improving diabetic and dementia disorders due to their high antioxidant, anti-diabetic, and anti-dementia activities.
\end{abstract}

Key words : Allium hookeri, antioxidant activity, a-glucosidase inhibition activity, acetylcholinesterase inhibition activity

\section{서 론}

삼채(Allium hookeri)는 히말라야 산맥 해발 1,400 4,200 미터 지역의 초 고랭지역이나 숲 또는 습지에서 자생하는 다년생초로, 마늘, 파, 양파, 부추 등과 같은 백합과 (Liliaceae)에 속한다(1). 미얀마와 인도에서는 삼채를 국민 채소로 애용할 뿐만 아니라 염증질환과 암 등의 민간요법으

*Corresponding author. E-mail : yoonky2441@ynu.ac.kr Phone : Tel : 82-53-810-2878, Fax : 82-53-810-4768

Received 23 September 2015; Revised 13 November 2015; Accepted 8 December 2015.

Copyright (c) The Korean Society of Food Preservation. All rights reserved.
로 오랫동안 사용하여 왔으며, 중국에서도 식용과 약용으 로 이용하고 있다(2). 단맛, 쓴맛, 매운맛이 난다고 하여 삼채(三菜), 또는 인삼 맛이 난다고 하여 삼채(蔘菜)라고 불린다. 삼채는 0.5 1 $\mathrm{m}$ 정도의 높이까지 자라고 뿌리, 뇌 두, 잎, 꽃대, 꽃으로 구성되어 있으며, 주로 뿌리와 잎을 식용으로 섭취한다. 삼채는 마늘에 비해 6배 많은 식이 유황 화합물을 함유하고 있으며, 또한 양파에 비해 높은 함량의 섬유소, 단백질, 폴리페놀 등을 함유하고 있다고 보고되고 있다(1). 미얀마 의학사전에는 다량의 식이유황이 포함되 어 있어 그 효능이 식이유황에서 기인된 것이라고 추측하고 있는데(3), 식이유황은 다수의 연구를 토대로 항암, 항염증, 항균효과 등이 보고되어 있다(4). 대체로 식이유황은 Allium 속 식물과 사포닌이 다량으로 함유되어 있는 인삼, 도라지, 
더덕 등에 많이 포함되어 있어, 삼채 또한 Allium속 식물로 다량 함유되어 다양한 생리활성을 나타낼 것으로 생각된다(5).

국내에는 2006년 삼채가 건강기능성 물질이 많이 함유된 작물로 소개된 이후 그 성분과 효능에 관심이 집중되어 미얀마로부터의 수입이 꾸준히 증가하고 있다. 2010년에 경남 하동 지역에 삼채 재배가 처음 도입된 이후 현재 농가 의 신소득 작물로서 인식됨으로써 전국 각 지역에서의 재배 량이 증가하고 있는 추세이며(6), 이에 따른 삼채에 대한 연구도 활발히 진행되고 있다. 현재까지 보고된 삼채에 관 한 연구는 삼채뿌리의 항염증 효과, 노지 및 시설재배 삼채 뿌리 및 잎의 이화학적 성분 및 DPPH 라디칼 소거능, 삼채 뿌리를 첨가한 김치의 품질특성 등 $(2,3,7,8)$ 이 있으며, 또한 선행연구를 통해 다량의 유리아미노산과 조사포닌이 함유 되어 있음을 확인하였다(5). 하지만 아직까지 국내산 삼채 에 대한 다양한 생리활성에 관한 연구는 여전히 부족한 실정이며, 더욱이 삼채 재배지 즉, 수입산 및 국내산 삼채에 대한 식품학적 및 기능적 특성 비교에 대한 연구보고는 전무하다. 따라서 본 연구에서는 국내 및 원산지인 미얀마 에서 재배된 삼채뿌리의 항산화, 항당뇨 및 항치매 활성 등을 비교, 분석하여 기능성 식품소재로의 가치를 확인함 과 동시에 국내산 삼채의 우수성을 확인하고자 하였다.

\section{재료 및 방법}

\section{실험재료}

본 실험에 사용된 삼채뿌리 중 국내산은 경상남도 하동 군에서 재배된 뿌리를 구입하였고, 미얀마산은 미얀마 샨 (Shan)주에서 재배된 뿌리를 구입하여 사용하였다. 구입한 시료는 이물질 제거 및 수세 하여 동결건조 후 $-40^{\circ} \mathrm{C}$ 에 보관 하여 사용하였다.

\section{추출물 제조 \\ 삼채뿌리의 기능성 측정을 위한 추출물은 삼각플라스크 에 동결건조 시료 $40 \mathrm{~g}$ 과 $80 \%$ methanol $200 \mathrm{~mL}$ 을 넣어 잘 섞은 다음 $60^{\circ} \mathrm{C}$ shaking water bath(KMC-8480SF, Vision Scientific Co., Seoul, Korea)에서 $100 \mathrm{rpm}$ 으로 5시간 동안 추출하고, 이를 $4^{\circ} \mathrm{C}, 8000 \mathrm{rpm}$ 에서 20 분간 원심분리한 다음 Whatman No. 1(Maidstone, England)로 여과하였다. 고형분 을 모아 다시 $80 \%$ methanol $200 \mathrm{~mL}$ 를 넣어 위의 방법으로 반복 추출 하였다. 얻어진 추출액을 감압농축(R-124, Buchi, Flawil, Swizerland)하고, 각각의 농축된 추출물은 동결건조 (FD-1, Eyela, Tokyo, Japan)하여 일정 량의 농도로 만들어 실험에 사용하였다.}

\section{총 폴리페놀 및 총 플라보노이드 함량 측정}

총 폴리페놀 함량은 Folin-Denis법(9)에 준하여 측정하였
다. 즉, 추출물을 증류수에 녹인 다음 시험관에 $0.2 \mathrm{~mL}$ 씩 취하고 여기에 Folin-ciocalteu's phenol reagent $0.2 \mathrm{~mL}$ 첨가 하여 잘 혼합하였다. 이를 실온에 3 분간 방치한 뒤, $10 \%$ $\mathrm{Na}_{2} \mathrm{CO}_{3} 0.4 \mathrm{~mL}$ 를 가하여 혼합하고 증류수 $4 \mathrm{~mL}$ 를 첨가하 였다. 실온에 1 시간 방치한 다음 $725 \mathrm{~nm}$ 에서 흡광도를 측정 하였다. 이 때 총 폴리페놀 화합물은 gallic acid(Sigma, St. Louis, MO, USA)를 이용하여 작성한 표준곡선으로부터 함량을 구하였다.

총 플라보노이드 함량은 Moreno 등(10)의 방법에 준하여 측정하였다. 추출물을 증류수에 녹인 다음 시험관에 0.5 $\mathrm{mL}$ 취하고 $10 \%$ aluminum nitrate와 $1 \mathrm{M}$ potassium acetate를 각각 $0.1 \mathrm{~mL}$ 씩 넣고, $80 \%$ ethanol을 $4.3 \mathrm{~mL}$ 를 가하여 혼합하 였다. 실온에서 40 분간 방치한 후 $415 \mathrm{~nm}$ 에서 흡광도를 측정하였다. 이 때 총 플라보노이드 함량은 quercetin(Sigma St. Louis, MO, USA)을 이용하여 작성한 표준곡선으로부터 환산하여 측정하였다.

\section{항산화 활성}

삼채뿌리 추출물의 항산화 활성을 확인하기 위해 $\mathrm{DPPH}$ 및 $\mathrm{ABTS}$ 라디칼 소거능, $\mathrm{Fe}^{2+}$ 킬레이팅 효과 그리고 환원력 을 측정하였으며, 이에 대한 $\mathrm{IC}_{50}$ (half maximal inhibition concentration)을 구하여 나타나내었다.

삼채뿌리 추출물의 DPPH 라디칼 소거능은 Blois(11)의 방법에 준하여 측정하였다. 안정한 유리 라디칼인 1,1-diphenyl2-picryl hydrazyl(DPPH, Sigma)에 대한 시료 용액과의 전자 공여 효과로써 이 반응에 의해 DPPH 라디칼이 감소하는 정도를 spectrophotometer(U-2900, Hitachi, Tokyo, Japan)를 이용하여 측정하였다. 각 추출물을 농도별로 제조하여 시 험관에 $0.5 \mathrm{~mL}$ 취하고, $0.1 \mathrm{mM} \mathrm{DPPH}$ 용액 $1 \mathrm{~mL}$ 를 가하여 10 초간 vortex mixing 하였다. 이를 실온에서 30 분간 반응시 켜 $520 \mathrm{~nm}$ 에서 흡광도를 측정하였다.

ABTS[2,2'-Azino-bis(3-ethylbenzothiazoline-6-sulfonic $\mathrm{acid})]$ 소거활성은 $\operatorname{Re}$ 등(12)의 방법을 일부 수정하여 실험 하였다. ABTS $7 \mathrm{mM}$ 과 potassium persulfate $2.45 \mathrm{mM}$ 을 증류수에 용해하여 12 16시간 동안 암소에 방치하여 $\mathrm{ABTS}$ cation 라디칼 $\left(\mathrm{ABTS}^{-1}\right)$ 을 형성시켰다. 이 용액을 $80 \%$ ethanol을 이용하여 $734 \mathrm{~nm}$ 에서 $0.700 \pm 0.002$ 의 흡광도 값을 갖도록 희석하였다. 증류수에 농도별로 희석한 추출 물 $50 \mu \mathrm{L}$ 를 시험관에 가한 다음 희석된 $\mathrm{ABTS}^{+}$용액 1 $\mathrm{mL}$ 를 첨가하고 실온에서 6분간 반응시켜 $734 \mathrm{~nm}$ 에서 흡광 도를 측정하였다.

삼채뿌리의 $\mathrm{Fe}^{2+}$ 킬레이팅 활성은 Dinis 등(13)의 방법을 변형하여 측정하였다. 추출물을 증류수에 녹여 농도별로 $1 \mathrm{~mL}$ 취한 뒤, $2 \mathrm{mM} \mathrm{FeCl}_{2}$ 와 $5 \mathrm{mM}$ Ferrozine[3-(2pyridyl)-5,6-diphenyl-1,2,4-triazine-4,4" -disulfonic acid]을 각각 $25 \mu \mathrm{L}$ 첨가하고 혼합하였다. 이를 실온에 10 분간 방치 한 다음 $562 \mathrm{~nm}$ 에서 흡광도를 측정하였다. 
환원력은 $\mathrm{Mau}$ 등(14)의 방법에 준하여 측정하였다. 추출 물을 증류수에 녹인 다음 $250 \mu \mathrm{L}$ 취하고, $0.2 \mathrm{M}$ sodium phosphate buffer( $\mathrm{pH}$ 6.6)와 $1 \%$ potassium ferricyanide $[\mathrm{KFe}$ $\left.(\mathrm{CN})_{6}\right]$ 각각 $250 \mu \mathrm{L}$ 를 첨가하여 $50^{\circ} \mathrm{C}$ 수욕에서 20 분간 반응 시킨 후, $10 \%$ trichloroacetic acid $250 \mu \mathrm{L}$ 를 첨가하였다. 위 반응액을 $25^{\circ} \mathrm{C}, 1000 \mathrm{rpm}$ 에서 10 분간 원심분리 하여 얻은 상등액 $500 \mu \mathrm{L}$ 에 증류수 $500 \mu \mathrm{L}$ 와 $0.1 \%$ ferric chloride $\left(\mathrm{FeCl}_{3} \cdot 6 \mathrm{H}_{2} \mathrm{O}\right) 100 \mu \mathrm{L}$ 를 첨가하여 혼합하였다. 이후 반응액 의 흡광도를 microplate reader(EPOCH, BioTek Instument Inc, Winooski, VT, USA)를 이용하여 $700 \mathrm{~nm}$ 에서 측정하였 다.

\section{$a-\mathrm{Glucosidase}$ 저해활성}

$a$-Glucosidase 저해활성은 Phan 등(15)의 방법에 따라 측 정하였다. 즉 각 농도별 sample $50 \mu \mathrm{L}$ 를 $0.2 \mathrm{U} / \mathrm{mL} 50 \mu \mathrm{L}$, $200 \mathrm{mM}$ potassium phosphate buffer(pH 6.8) $50 \mu \mathrm{L}$ 와 혼합하 여 $37^{\circ} \mathrm{C}$ 에서 15 분간 배양한 후 $3 \mathrm{mM} \rho \mathrm{NPG}(\rho$-nitrophenyl-a -D-glucopyranoside, Sigma) $100 \mu \mathrm{L}$ 를 가하여 $37^{\circ} \mathrm{C}$ 에서 10 분 간 반응시켰다. 이후 반응액에 $0.1 \mathrm{M} \mathrm{NaOH} 50 \mu \mathrm{L}$ 로 반응을 정지시키고 $405 \mathrm{~nm}$ 에서 흡광도를 측정하였다. Sample 무첨 가구는 negative control로 사용하였고, 기질 무첨가구는 blank로 사용하였다. 비교를 위해 acarbose(Sigma)를 positive control로 사용하였으며, 효소활성의 저해정도는 다음식의 의해 산출되었다.

*Inhibition $(\%)=\left[1-\left(\mathrm{ABS}_{\text {sample }}-\mathrm{ABS}_{\text {blank }}\right) / \mathrm{ABS}_{\text {control }}\right] \times 100$ $\mathrm{ABS}_{\text {sample: }}$ Absorbance of the experimental sample $\mathrm{ABS}_{\text {blank: }}$ Absorbance of the blank

$\mathrm{ABS}_{\text {control: }}$ : Absorbance of the negative control

\section{Acethylcholinesterase (AChE) 저해활성 측정}

삼채뿌리의 acethylcholinesterase( $\mathrm{AChE})$ 저해활성은 Ellman 등(16)의 방법을 응용하여 측정하였다. $200 \mathrm{mM}$ phosphate buffer에 녹인 sample $200 \mu \mathrm{L}$, DTNB $80 \mu \mathrm{L}, 0.2$ unit $/ \mathrm{mL}$ acethylcholinesterase $10 \mu \mathrm{L}$ 를 micro well plate에 넣고 혼합한 뒤, $25^{\circ} \mathrm{C}$ 에서 5 분간 incubation 하였다. 배양 후 acetylcholine iodide $15 \mu \mathrm{L}$ 를 넣고 다시 $25^{\circ} \mathrm{C}$ 에서 5 분간 incubation 한 뒤, $405 \mathrm{~nm}$ 에서 흡광도를 측정하였다. Control 은 sample 대신 동량의 phosphate buffer를 사용하였으며, 효소활성의 저해정도는 다음 식에 의하여 산출하였다.

*Inhibition $(\%)=\left(1-\left(\mathrm{ABS}_{\text {sample }} / \mathrm{ABS}_{\text {control }}\right)\right) \times 100$

$\mathrm{ABS}_{\text {sample: }}$ Absorbance of the experimental sample

$\mathrm{ABS}_{\text {control: }}$ Absorbance of the control

\section{통계처리}

본 실험결과는 3반복으로 수행된 평균값과 표준편차로 나타내었으며, 각 실험결과에 대한 통계분석은 SPSS(Ver.
20, Chicago, IL, USA) 통계 프로그램을 이용하여 시료간의 유의차로 $\mathrm{p}<0.05$ 수준에서 $\mathrm{t}$-test로 검증하였다. 또한 항당 뇨 및 항치매 활성 실험은 $\mathrm{p}<0.05$ 수준에서 일원배치 분산 분석법을 시행하고 각 실험군 평균치간의 유의적 차이는 Duncan's multiple range test로 검증하였다.

\section{결과 및 고찰}

\section{총 폴리페놀 및 플라보노이드 함량}

폴리페놀계 물질은 식물체에 널리 분포되어 있으며 한 분자 내에 2개 이상의 phenolic hydroxyl(-OH)기를 가지는 방향족 화합물을 총칭하며, 산화-환원반응에서 기질로 작 용한다. 폴리페놀화합물의 종류로는 phenolic acid, flavonoids, lignans, stilbenes 등이 있으며, 항산화활성을 비롯하여 심혈관계 질환예방, 항암, 항염증, 항고혈압 활성 을 가진다(17). 삼채뿌리의 총 폴리페놀 및 플라보노이드 함량을 측정한 결과는 Table 1 과 같다. 총 폴리페놀함량은 국내산 삼채뿌리 $5.27 \mathrm{mg} \mathrm{GAE} / \mathrm{g}$, 미얀마산 삼채뿌리 4.80 $\mathrm{mg} \mathrm{GAE} / \mathrm{g}$ 으로 국내산 삼채뿌리가 유의적으로 높은 함량 을 나타내어 재배지에 따라 함량이 차이를 보이는 것을 알 수 있었다. 총 플라보노이드 함량 또한 국내산 삼채뿌리 $0.35 \mathrm{mg} \mathrm{QE} / \mathrm{g}$, 미얀마산 삼채뿌리 $0.24 \mathrm{mg} \mathrm{QE} / \mathrm{g}$ 으로 유의 적인 차이를 보여 대부분의 식물에서 폴리페놀함량이 높을 경우 플라보노이드함량 또한 높다는 보고와 동일하게 나타 났다(18). 이상의 결과에서 국내산 삼채뿌리가 미얀마산 삼채뿌리보다 더 높은 총 폴리페놀 및 플라보노이드함량을 보여 항산화 활성이 더 뛰어날 것으로 추측된다.

Table 1. Total polyphenol and flavonoid contents of Allium hookeri root

\begin{tabular}{ccc}
\hline Sample $^{1)}$ & $\begin{array}{c}\text { Total polyphenols } \\
\text { (mg GAE/g extract powder) }\end{array}$ & $\begin{array}{c}\text { Total flavonoids } \\
\text { (mg QE/g extract powder) }\end{array}$ \\
\hline KR & $\left.\left.5.27 \pm 0.13^{2 *}\right)^{* 3}\right)$ & $0.35 \pm 0.01^{*}$ \\
MR & $4.80 \pm 0.11$ & $0.24 \pm 0.02$ \\
\hline
\end{tabular}

${ }^{1)} \mathrm{KR}$, Korea Allium hookeri root grown in Korea; MR, Allium hookeri root grown in Myanmar.

${ }^{2)}$ Mean \pm SD ( $(n=3)$.

${ }^{3)}$ Significant differences between KR and MR according to the t-test at $p<0.05$.

\section{항산화 활성}

삼채뿌리의 항산화 활성을 측정하기 위하여 $\mathrm{DPPH}$ 라디 칼 소거능, $\mathrm{ABTS}$ 라디칼 소거능, $\mathrm{Fe}^{2+}$ 킬레이팅 활성, 환원 력을 조사하였고, 라디칼 및 킬레이팅 화합물의 농도를 $50 \%$ 감소시키거나 0.5 의 흡광도를 가지는데 필요한 시료의 농도인 $\mathrm{IC}_{50}$ 을 측정한 결과는 $\mathrm{Fig} .1$ 과 같다. $\mathrm{DPPH}$ 라디칼 소거능의 $\mathrm{IC}_{50}$ 값은 국내산 삼채뿌리 $6.53 \mathrm{mg} / \mathrm{mL}$, 미얀마산 삼채뿌리 $5.31 \mathrm{mg} / \mathrm{mL}$ 로 미얀마산 삼채뿌리의 $\mathrm{DPPH}$ 라디 
칼 소거효과가 더 뛰어난 것으로 나타났다. ABTS 라디칼 소거능의 $\mathrm{IC}_{50}$ 값은 국내산 삼채뿌리 $14.75 \mathrm{mg} / \mathrm{mL}$, 미얀마 산 삼채뿌리 $16.93 \mathrm{mg} / \mathrm{mL}$ 로 국내산 삼채뿌리의 소거활성 이 더 뛰어나 DPPH 라디칼 소거능의 결과와는 다른 경향을 나타내었다. 이는 두 측정방법에 이용되는 라디칼의 종류 가 각각 다르고, 기질과 항산화물질과의 결합정도의 차이 로 인해 라디칼의 소거능력에서도 차이가 생기는 것으로 판단된다. 세이지로부터 추출된 10 종류의 폴리페놀 화합물 중 rosmarinic acid, 6-O- $(E)$ - feruloyl-( $\alpha$ and $\beta)$-glucopyranoside, (-)-isolariciresinol 3a-O-B-D-glucopyranoside, luteolin-7- $O$ $\beta$-glucopyranoside 만이 $\mathrm{DPPH}$ 라디칼과 결합하여 높은 소거능을 보인 반면, $\mathrm{ABTS}$ 라디칼은 10 종류의 폴리페놀 화합물과 모두 결합하였으나 그 소거능은 매우 약하게 나타 났다(19). 따라서 국내산 삼채뿌리에는 ABTS 라디칼과 결 합력이 강한 폴리페놀 화합물의 함량이 높을 것으로 추측되 며, 향후 이에 대한 추가 연구가 필요할 것으로 판단된다.

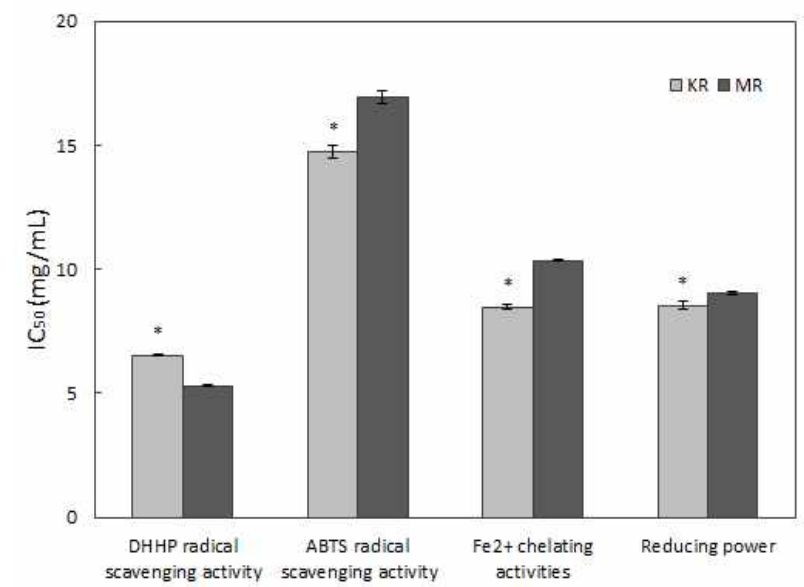

Fig. 1. $\mathrm{IC}_{50}$ of DPPH radical scavenging, ABTS radical scavenging, and ferrous ion chelating activities, and reducing power of Allium hookeri root.

KR, Korea Allium hookeri root grown in Korea; MR, Allium hookeri root grown in Myanmar.

Mean \pm SD $(n=3)$.

${ }^{*}$ Significant differences between $\mathrm{KR}$ and MR according to the t-test at $\mathrm{p}<0.05$.

$\mathrm{Fe}^{2+}$ 킬레이팅 활성은 ferrozine을 이용하여 $\mathrm{Fe}^{2+}$ 이온과 complex를 형성해 붉은색을 나타내지만, 킬레이팅 효과를 가지는 물질에 의해 붉은색이 탈색되는 정도를 측정하여 나타낸다. 삼채뿌리의 $\mathrm{Fe}^{2+}$ 킬레이팅 활성의 $\mathrm{IC}_{50}$ 값은 국내 산 삼채뿌리 $8.47 \mathrm{mg} / \mathrm{mL}$, 미얀마산 삼채뿌리 $10.36 \mathrm{mg} / \mathrm{mL}$ 으로 국내산 삼채뿌리가 더 높은 소거능을 보였다. 환원력 은 활성산소와 유리기에 전자를 공여하는 능력으로, 환원 력이 높을수록 녹색에 가깝게 발색되며 높은 흡광도를 나타 낼수록 항산화 활성이 높다(20). 삼채뿌리의 환원력의 $\mathrm{IC}_{50}$ 값을 측정한 결과, 국내산 삼채뿌리는 $8.53 \mathrm{mg} / \mathrm{mL}$, 미얀마 산 삼채뿌리는 $9.03 \mathrm{mg} / \mathrm{mL}$ 으로 국내산 삼채뿌리가 더 높은 환원력을 보였다.
일반적으로 폴리페놀과 항산화 활성과의 상관관계에 대 한 연구결과를 살펴보면, 폴리페놀과 DPPH 라디칼과의 상관관계에 대해 Kwon 등(21)은 총 페놀함량이 높은 분획 물에서 가장 높은 DPPH 라디칼 소거능을 보였고, Kang 등(22)은 환원력이 클수록 DPPH 라디칼 소거능이 높다고 하여 페놀화합물이 DPPH 라디칼 소거능과 밀접한 상관관 계를 가진다고 보고하였다. 또한 $\mathrm{ABTS}$ 라디칼도 폴리페놀 및 플라보노이드의 함량이 많을수록 우수하다고 알려져 있다. 이는 페놀성 화합물이 반응 중 alkyl 라디칼 또는 alkylperoxy 라디칼에 수소를 공여해 라디칼을 제거하여 산화를 억제하기 때문이다(23). Pasko 등(24)과 Dlamini 등 (25)은 폴리페놀함량이 많을수록 높은 환원력을 보인다고 보고하였다. 따라서 이상의 결과에서 국내산 삼채뿌리가 $\mathrm{ABTS}$ 라디칼과 $\mathrm{Fe}^{2+}$ 킬레이팅 활성 및 환원력이 미얀마산 삼채뿌리에 비해 높게 나타난 것은 높은 폴리페놀 함량 (Table 1)에 기인한 것으로 판단된다. 반면 미얀마산 삼채뿌 리가 국내산 삼채에 비해 DPPH 라디칼의 소거능이 다소 우수한 것으로 나타나 미얀마산 삼채뿌리에는 DPPH 라디 칼과 결합력이 강한 폴리페놀 화합물의 함량이 높을 것으로 추측된다.

\section{항당뇨 활성}

장내 a-glucosidase는 소장점막의 미세융모막에 존재하 는 효소로서 다당류의 탄수화물을 단당류로 분해하는 탄수 화물의 소화에 필수적인 효소이다. 탄수화물은 amylase에 의해 올리고당으로 분해되고 a-glucosidase에 의해 포도당 으로 분해되는데, a-glucosidase inhibitor는 a-glucosidase에 결합함으로써 단당류인 포도당이 분해·흡수되는 것을 방해 하여 식후 혈당을 조절한다(26). 삼채뿌리의 항당뇨 활성을 분석한 결과(Fig. 2), 삼채뿌리 추출물에 대한 a-glucosidase 억제효과는 농도가 높아질수록 증가하는 경향을 보였고, 국내산 삼채뿌리의 억제효과가 유의적으로 높은 활성을 나타내었다. $2 \mathrm{mg} / \mathrm{mL}$ 농도에서 국내산 삼채뿌리는 $63.13 \%$, 미얀마산 삼채뿌리는 $31.50 \%$ 의 억제효과를 나타내었으며, $8 \mathrm{mg} / \mathrm{mL}$ 농도에서 국내산 삼채뿌리와 미얀마산 삼채뿌리 각각 $93.75 \%, 86.89 \%$ 로 높은 억제효과를 나타내었다. 또한 현재 a-glucosidase inhibitor로 시판되고 있는 acarbose의 저 해효과와 비교한 결과, 국내산 삼채뿌리는 모든 농도에서 acarbose에 비해 유의적으로 높은 억제활성을 나타내었다. 반면 미얀마산 삼채뿌리는 $6 \mathrm{mg} / \mathrm{mL}$ 이하의 농도에서 acarbose에 비해 낮은 저해활성을, $8 \mathrm{mg} / \mathrm{mL}$ 이상에서 acarbose와 유사한 저해활성을 나타내었다. Acarbose는 뛰 어난 혈당강하효과를 보이지만 장기간 복용할 경우 복부팽 만감, 설사 등 소화기계 부작용이 따르고, 염증성 장 질환이 나 간기능장애가 있을 경우 주의를 요하는 약물이다 $(27,28)$. Jeong 등(29)은 약용식물 추출물의 a-glucosidase 저해활성, 총 폴리페놀, 총 플라보노이드 함량과의 상관관 
계를 분석한 결과, a-glucosidase 저해활성은 총 폴리페놀 함량 $(\mathrm{r}=0.792, \mathrm{p}<0.01)$ 및 총 플라보노이드 함량 $(\mathrm{r}=0.588$, $\mathrm{p}<0.01)$ 과 양의 상관계수를 보인다고 보고하였다. 이는 본 연구에서 총 폴리페놀함량이 높은 국내산 삼채뿌리의 저해 활성이 더 높게 나타난 실험결과와 일치하였으며, 따라서 a-glucosidase를 저해하는 mechanism에 폴리페놀과 플라보 노이드가 관여하는 것으로 판단된다. 이상의 결과에서 천 연소재인 삼채뿌리 특히 국내산 삼채뿌리는 높은 $a$ -glucosidase 저해활성으로 가지는 것으로 나타나 식후 혈당 조절제로서의 활용가능성이 뛰어날 것으로 판단된다.

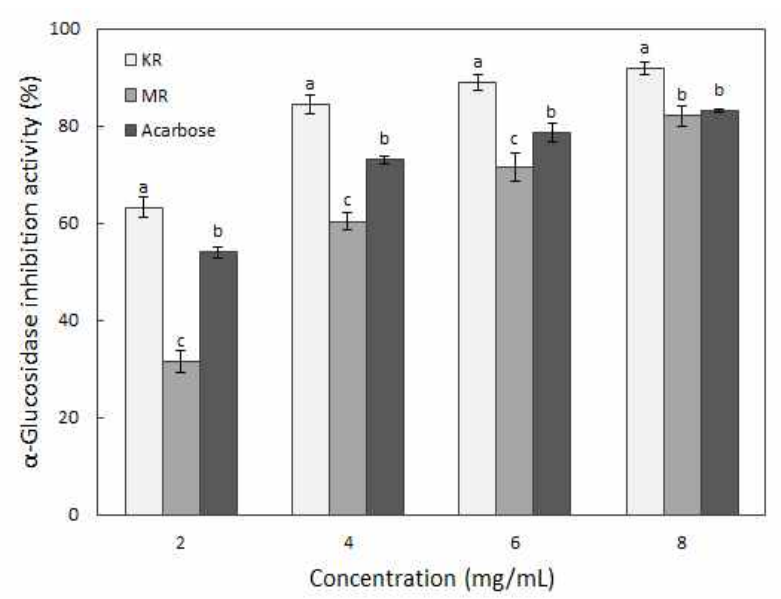

Fig. 2. a-Glucosidase inhibition activity of Allium hookeri root.

$\mathrm{KR}$, Korea Allium hookeri root grown in Korea; MR, Allium hookeri root grown in Myanmar.

Mean \pm SD $(n=3)$.

Values in the column with different superscript letters are significantly different at $\mathrm{p}<0.05$.

\section{항치매 활성}

Acetylcholine은 신경조직에 존재하며 시냅스에서 신경 자극을 전달하는 화학물질로 신경말단에서 분비된다. 체내 의 신경전달이 원활하게 이루어지기 위해서는 acetylcholineesterase $(\mathrm{AChE})$ 의 활성이 중요하다. 알츠하이머환자의 경우 $\mathrm{AChE}$ 에 의해 acetylcholine의 양이 정상인에 비해 $50 \%$ 감소되어 인지기능이 저하된다고 알려져 있다(30). AChE는 acetylcholine 을 acetate와 choline으로 가수분해 시키는 작용을 하며, 현 재는 이러한 $\mathrm{AChE}$ 를 억제하여 acetylcholine의 양을 증가시 키는 방법을 바탕으로 인지기능을 호전시키고 치매치료에 사용하고 있다(31,32). 따라서 치매의 예방 및 치료개선 효 과를 확인하기 위해 삼채뿌리로 $\mathrm{AChE}$ 활성 억제정도를 측정한 결과(Fig. 3), 삼채뿌리의 농도가 증가할수록 높은 저해율을 나타냈으며, 추출물의 모든 농도에서 국내산 삼 채뿌리의 저해활성도가 미얀마산 삼채뿌리보다 더 높게 나타났다. $10 \mathrm{mg} / \mathrm{mL}$ 농도에서 국내산 삼채뿌리의 저해활 성도는 $13.45 \%$, 미얀마산 삼채뿌리 $10.89 \%$ 로 나타났으며, $50 \mathrm{mg} / \mathrm{mL}$ 농도에서는 국내산 삼채뿌리 $51.44 \%$, 미얀마산 삼채뿌리 $44.33 \%$ 의 저해활성효과를 보였다. 다수의 연구
(33-35)에서 alkaloids 또는 flavonoid가 $\mathrm{AChE}$ 활성을 억제 하는 효과가 있다고 보고하고 있으며, Jeong 등(36)은 대표 적 파속식물인 마늘의 황 화합물이 $\mathrm{AChE}$ 활성을 저해한다 고 보고하였다. 따라서 국내산 삼채뿌리의 우수한 $\mathrm{AChE}$ 억제효과는 국내산 삼채뿌리의 높은 flavonoid 함량뿐만 아니라 황(S) 및 조사포닌의 높은 함량에 기인한 것으로 판단된다(4).

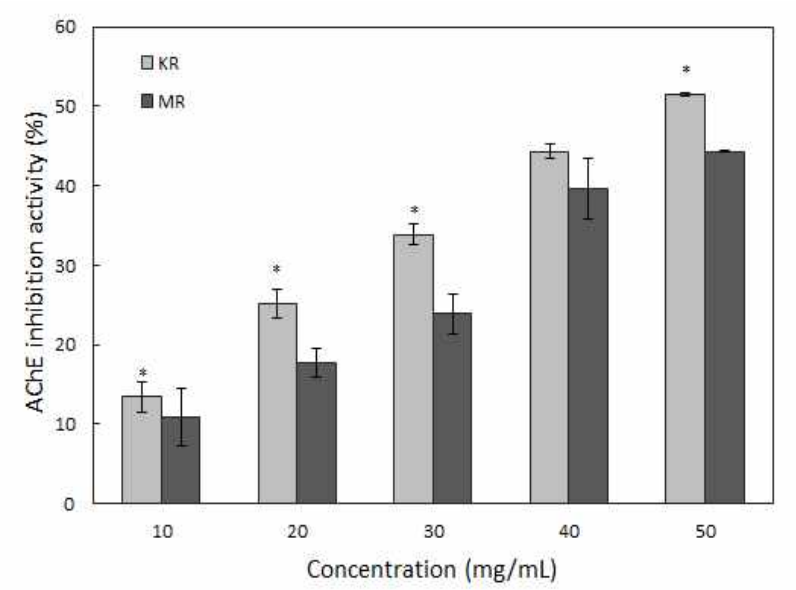

Fig. 3. Acetylcholinesterase (AChE) inhibition activity of Allium hookeri root.

KR, Korea Allium hookeri root grown in Korea; MR, Allium hookeri root grown in Myanmar.

Mean \pm SD ( $\mathrm{n}=3)$.

"Significant differences between $\mathrm{KR}$ and $\mathrm{MR}$ according to the $t$-test at $\mathrm{p}<0.05$.

\section{요 약}

본 연구는 선행 연구된 삼채뿌리의 뛰어난 영양성을 토 대로 기능성 식품소재로의 이용가능성을 확인하고 활용도 를 높이고자 국내산 및 미얀마산 삼채뿌리의 항산화 및 생리활성을 측정하였다. 삼채뿌리의 총 폴리페놀과 총 플 라보노이드 함량은 국내산 삼채뿌리가 각각 $5.27 \mathrm{mgGAE} / \mathrm{g}$, $0.35 \mathrm{mgQE} / \mathrm{g}$, 미얀마산 삼채뿌리가 각각 $4.80 \mathrm{mgGAE} / \mathrm{g}$, $0.24 \mathrm{mgQE} / \mathrm{g}$ 으로 국내산 삼채뿌리가 더 높은 함량을 나타 냈다. 삼채뿌리의 항산화력을 측정한 결과 DPPH 라디칼 소거능은 미얀마산이 더 높은 활성을 보였지만, ABTS 라디 칼 소거능과 $\mathrm{Fe}^{2+}$ 킬레이팅 활성, 환원력은 국내산이 더 높은 활성을 보였다. $a$-Glucosidase 저해활성은 국내산의 저해활성이 미얀마산 삼채뿌리의 저해활성보다 더 높았으 며 대조구인 acarbose에 비해서도 우수한 저해활성을 보였 다. Acetylcholinesterase 저해 활성을 측정한 결과, 50 $\mathrm{mg} / \mathrm{mL}$ 농도에서 국내산 삼채뿌리가 $51.44 \%$ 로 $44.33 \%$ 의 저해활성을 보인 미얀마산 삼채뿌리보다 더 높은 저해활성 을 보였다. 본 연구를 통해 삼채뿌리 특히 국내산 삼채뿌리 는 높은 항산화 활성, a-glucosidase 및 acetylcholinesterase 저해 활성을 보여 혈당조절제, 치매예방 및 개선제로써의 
활용가능성이 큰 것으로 확인되었으며, 이로써 기능성 식 품소재로의 활용이 증가될 것으로 판단된다. 하지만 향후 국내산 삼채의 우수성을 검증하기 위하여 여러 지역에서 재배된 삼채의 기능성 분석이 필요할 것으로 판단된다.

\section{References}

1. Ayam VS (2011) Allium hookeri, Thw. Enum. A lesser known terrestrial perennial herb used as food and its ethnobotanical relevance in manipur. Afr J Food Agric Nutr Dev, 11, 5389-5412

2. Kim CH, Lee MA, Kim TW, Jang, JY, Kim, HJ (2012) Anti-inflammatory effect of Allium hookeri root methanol extract in LPS-induced RAW264.7 cells. J Korean Soc Food Sci Nutr, 41, 1645-1648

3. Bae GC, Bae DY (2012) The anti-inflammatory effects of ethanol extract of Allium hookeri cultivated in South Korea. Korean J Herbology, 27, 55-61

4. Kwon EJ, Ryu DY, Surh JH (2013) Quality characteristics of onions applied with methylsulfonylmethane (MSM) during cultivation. Korean J Food Sci Technol, 45, 213-220

5. Park JY, Yoon KY (2014) Comparison of the nutrient composition and quality of the root of Allium hookeri grown in Korea and Myanmar. Korean J Food Sci Technol, 46, 544-548

6. Oh JY, Kim WI, An CG, Kim HD, Hong KP (2014) The growth characteristics of Allium hookeri as altitudes in Gyeongnam. Korean J Hor Sci Technol, 32(sup), 79-80

7. Won JY, Yoo YC, Kan EJ, Yagn H, Kim GH, Seong BJ, Kim SI, Han SH, Lee SS, Lee KS (2013) Chemical components, DPPH radical scavenging activity and inhibitory effects on nitric oxide production in Allium hookeri cultivated under open field and greenhouse conditions. J Korean Soc Food Sci Nutr, 42, 1351-1356

8. You BR, Kim HJ (2013) Quality characteristics of Kimchi added with Allium hookeri root. J Korean Soc Food Sci Nutr, 42, 1649-1655

9. Folin O, Denis W (1912) On phosphotungstic-phosphomolybdic compounds as color reagents. J Biol Chem, 12, 239-243

10. Moreno MIN, Isla MI, Sampietro AR, Vattuone MA (2000) Comparison of the free radical-scavenging activity of propolis from several regions of Argentina. J Ethnopharmacol, 71, 109-114

11. Blois MS (1958) Antioxidant determinations by the use of a stable free radical. Nature, 181, 1199-1200
12. Re R, Pellegrini N, Proteggente A, Pannala A, Yang M, Rice-Evans C (1999) Antioxidant activity applying an improved ABTS radical cation decolorization assay. Free Radical Bio Med, 26, 1231-1237

13. Dinis TC, Madeira VMC, Almeida LM (1994) Action of phenolic derivatives (acetaminophen, salicylate, and 5-aminosalicylate) as inhibitors of membrane lipid peroxidation and as peroxyl radical scavengers. Arch Biochem Biophys. 315, 161-169

14. Mau JL, Lin HC, Song SF (2002) Antioxidant properties of several specialty mushrooms. Food Res Int, 35, 519-526

15. Phan MAT, Wang J, Tang J, Lee YZ, Ng K (2013) Evaluation of a-glucosidase inhibition potential of some flavonoids from Epimedium brevicornum LWT-Food Sci Technol, 53, 492-498

16. Ellman GL, Courtney KD, Andres V, Featherstone RM (1961) A new and rapid colorimetric determination of acetylcholinesterase activity. Biochem Pharmacol, 7, 88-95

17. Yu MH, Im HG, Lee HJ, Ji YJ, Lee IS (2006) Components and their antioxidative activities of methanol extracts from sarcocarp and seed of Zizyphus jujuba var. Inermis rehder. Korean J Food Sci Technol, 38, 128-134

18. Choi SY, Lim SH, Kim JS, Ha TY, Kim SR, Kang KS, Hwang IK (2005) Evaluation of the estrogenic and antioxidant activity of some edible and medicinal plants. Korean J Food Sci Technol, 37, 549-556

19. Wang M, Li J, Rangarajan M, Shao Y, LaVoie EJ, Huang TC, Ho CT (1998) Antioxidative phenolic compounds from sage (Salvia officinalis). J Agr Food Chem, 46, 4869-4873

20. Kim JS, Lee YJ, Yang JF, Sa YJ, Kim MO, Park JH, Park DS, Yu CY, Kim MJ (2013) Biological activity of Sorghum bicolor M. cv. Bulgeunjangmoksusu extracts. Korean J Plant Res, 26, 111-118

21. Kwon HN, Park JR, Jeon JR (2008) Antioxidative and hepatoprotective effects of Acer tegmentosum M. extracts. J Korean Soc Food Sci Nutr, 37, 1389-1394

22. Kang YH, Park YK, Oh SR, Moon KD (1995) Studies on the physiological functionality of pine needle and mugwort extracts. Korean J Food Sci Technol, 27, 978-984

23. Labuza TP, Dugan Jr L (1971) Kinetics of lipid oxidation in foods. Crit Rev Food Sci, 2, 355-405

24. Pasko P, Barton H, Zagrodzki P, Gorinstein S, Folta M, Zachwieja Z (2009) Anthocyanins, total polyphenols and 
antioxidant activity in amaranth and quinoa seeds and sprouts during their growth. Food Chem, 115, 994-998

25. Dlamini NR, Taylor J, Rooney LW (2007) The effect of sorghum type and processing on the antioxidant properties of African sorghum-based foods. Food Chem, 105, 1412-1419

26. Choi HJ, Jeong YK, Kang DO, Joo WB (2008) Inhibitory effects of four solvent fractions of Alnus firma on a -amylase and a-glucosidase. J Life Sci, 18, 1005-1010

27. Jeong IK, Chung JH, Min YK, Lee MS, Lee MK, Kim KW, Chung YE, Park JY, Hong SK, Lee KU (2002) Comparative study about the effects of acarbose and voglibose in type 2 diabetic patients. J Korean Diabetes Assoc, 26, 134-145

28. Tsujimoto T, Shioyama E, Moriya K, Kawaratani H, Shirai Y, Toyohara M, Mitoro A, Yamao J, Fujii H, Fukui $\mathrm{H}$ (2008) Pneumatosis cystoides intestinalis following alpha-glucosidase inhibitor treatment: a case report and review of the literature. World J Gastroenterol, 14, 6087-6092

29. Jeong HJ, Lee SG, Lee EJ, Park WD, Kim JB, Kim HJ (2010) Antioxidant activity and anti-hyperglycemic activity of medicinal herbal extracts according to extraction methods. Korean J Food Sci Technol, 42,
571-577

30. Talesa VN (2001) Acetylcholinesterase in alzheimer's disease. Mech Ageing Dev, 122, 1961-1969

31. Houghton PJ, Ren Y, Howes MJ (2006) Acetylcholinesterase inhibitors from plants and fungi. Nat Prod Rep, 23, 181-199

32. Muir JL (1997) Acetylcholine, aging, and alzheimer's disease. Pharmacol Biochem Behav, 56, 687-696

33. Berkov S, Bastida J, Nikolova M, Viladomat F, Codina C (2008) Rapid TLC/GC-MS identification of acetylcholinesterase inhibitors in alkaloid extracts. Phytochem Analysis, 19, 411-419

34. Mahinda S, Ahn CB, Je JY (2010) Enzymatic extracts from edible red algae, Porphyra tenera, and their antioxidant, anti-acetylcholinesterase, and anti-inflammatory activities. Food Sci Biotechnol, 19, 1551-1557

35. Jung MK, Park MS (2007) Acetylcholinesterase inhibition by flavonoids from Agrimonia pilosa. Molecules, 12, 2130-2139

36. Jeong HR, Jeong JH, Jo YN, Shin JH, Kang MJ, Sung NJ, Heo HJ (2011) Antioxidant and acetylcholinesterase inhibitory effect of aged raw garlic extracts. J Agr Life Sci, 45, 113-120 